\title{
Stock Assessment and Estimation of Maximum Sustainable Yield for Tilapia Stock (Oriocromis niloticus) in Lake Hawassa, Ethiopia
}

\author{
Negese Kebtieneh", Yitayal Alemu, Mulugeta Tesfa \\ Department of Wildlife, Wetland and Fishery Management, Wondo Genet College of Forestry and Natural Resources, Hawassa University, \\ Shashemene, Ethiopia
}

\section{Email address:}

tamenenege@gmail.com (N. Kebtieneh), yitayalemu@gmil.com (Y. Alemu), muletesfa@gmail.com (M. Tesfa)

*Corresponding Author

\section{To cite this article:}

Negese Kebtieneh, Yitayal Alemu, Mulugeta Tesfa. Stock Assessment and Estimation of Maximum Sustainable Yield for Tilapia Stock (Oriocromis niloticus) in Lake Hawassa, Ethiopia. Agriculture, Forestry and Fisheries. Vol. 5, No. 4, 2015, pp. 97-107. doi: $10.11648 /$ j.aff.20160504.12

Received: September 1, 2015; Accepted: September 16, 2015; Published: July 18, 2016

\begin{abstract}
The study was conducted on Lake Hawassa, one of the series Ethiopian rift valleys lakes. Data were collected from the area where fish are landed at one major landing site called fish market informally known as Amora Gedel, for one year (365days) on a daily basis. The length composition of tilapia caught by the fishery, total tilapia yield, fishing effort expanded as well as the price of tilapia and the cost of fishing operation were the basic information collected from the site. The aim of the analysis was to assess sustainability of fish stock, fishing level and to predict optimum yield and the bio-economic features of Lake Hawassa fisheries. Jones length based cohort analysis Model and length-based Thompson and Bell yield Prediction Model have been employed to estimate the maximum sustainable yield and maximum economic yield with their corresponding effort level. The estimated current annual yield was 182.94 tons of tilapia with the annual sale value of 4,158,760 ETB and 3,199,210 ETB of net profit for the fishermen cooperative. The predicted value of MSY was 186.72 tons/yr and this is obtained at fishing mortality factor of 1.6. And also MEY was 178.20 tons/yr and this is obtained at fishing mortality factor of 0.8 . The fishery sector was found inefficient; the production was below its maximum sustainable yield level. Therefore harvest level should increase to its maximum sustainable yield level this might be possible by reducing the operating cost in order to increase both the level of yield as well as the net profit gained by the fishery sector.
\end{abstract}

Keywords: Stock Assessment, Optimum Yield, Virtual Population Analysis, Fishery Management, Lake Hawassa

\section{Introduction}

The basic purpose of stock assessment is to provide decision makers with the information necessary to make rational choices on the optimum level of exploitation of aquatic living resources such as fish. Aquatic living resources are limited but renewable, and fish stock assessment may be described as the search for the exploitation level, which in the long run gives the maximum sustainable bio-economic yield in weight from fishery [1]

Fish resource utilization is the primary and an important economic activity. Its purpose is to provide a flow of benefits to human society; it serves as a food because of its rich nutritional value in provision of protein. The global capture fisheries production in 2008 was reported by FAO, Fisheries and Aquaculture Department, as 90 million tones, with an estimated first-sale value of US\$93.9 billion, comprising about 80 million tons from marine waters and 10 million tons from inland waters. [2]

However, the proportion of marine fish stocks underexploited or moderately exploited declined from 40 percent in the mid-1970s to 15 percent in 2008, whereas the proportion of overexploited, depleted or recovering stocks increased from 10 percent in 1974 to 32 percent in 2008 [2]. The above status of fisheries was also stated by [3] as "if the earth's oceans were a human being they'd be rushed to the hospital, admitted to the intensive care unit and listed in grave condition." This explanation indicates the degree of 
severity of marine fish depletion. They continued their saying as the great geographic expansion of fisheries and although some further developments of resources beyond national authority are frequently occurring; more and more species are moving into the fully exploited and overexploited categories.

In the early 1970 s, FAO estimated the potential fish harvest of resources of the oceans at close to 100 million tones, but unlikely the harvest was not more than 80 million tones. On the contrary since the mid-1990s and throughout the 2000s, studies have predicted the rapid decline of marine fisheries worldwide. In looking at the total global capture statistics collected by FAO almost 40 years after those analyzed in 1970 s, they found the catch trends has very rarely to be described as stable, it is likely to say it has not been in sustainable yield [2].

The major thing that makes management and control of fisheries difficult is its property right regime. Under a well-defined property regime the individual fisherman would not exceed the maximum economic yield. However, in an open access situation, the individual fisherman will try to fish as much as he can before somebody else takes the fish. Since all fishermen act this way, the consequence is not only economic but also biological overfishing Just like Hardin's "tragedy of commons". The main cause that prevents a sustainable use of the common property resource is overfishing either by increasing the fishing effort or by catching immature fish. The factors that lead to that cause can be categorized into economic, socio-cultural and political factors [4].
Like other Ethiopian lakes, Lake Hawassa has also been overfished in the past decades because of the heavy pressure exerted on the lake fisheries. According to [5], it is in critical condition compared to the other Ethiopian lakes.

The best possible supplies of fish for the future generation could be guaranteed when all those involved in fisheries work together to conserve and manage fish resources and habitats. Giving emphasis to the necessity of fisheries management, in order for countries to manage their fisheries they need to have clear and well-organized fishing policies which are developed in cooperation with all groups that have an interest in fisheries [6]. In order to overcome the problems faced to the fisheries sector, stock assessment and bio economic prediction play an important role for the increment of knowledge and up-to-date information on the status of fishery.

\section{Methodology}

\subsection{Site Description}

\subsubsection{Location}

Lake Hawassa is the smallest of the eight lakes in the Rift valley of Ethiopia. It is Located in the SNNPRS, bordering the eastern side of Hawassa city, which is located $275 \mathrm{~km}$ south of Addis Ababa (Figure 1). Geographically, the lake lies between $6^{\circ} 33^{\prime}-7^{\circ} 33^{\prime} \mathrm{N}$ and $38^{\circ} 22^{\prime}-38^{\circ} 29^{\prime} \mathrm{E}$ at an altitude of 1680 ma.s.l. The lake has a surface area of $90 \mathrm{~km}^{2}$, a mean depth of $11 \mathrm{~m}$, a volume of $1.036 \times 109 \mathrm{~m}^{3}$ and a drainage area of 1,250 $\mathrm{km}^{2}$. It is a terminal lake with no surface out flow and receives surface inflow through Tikur Wuha River [5].

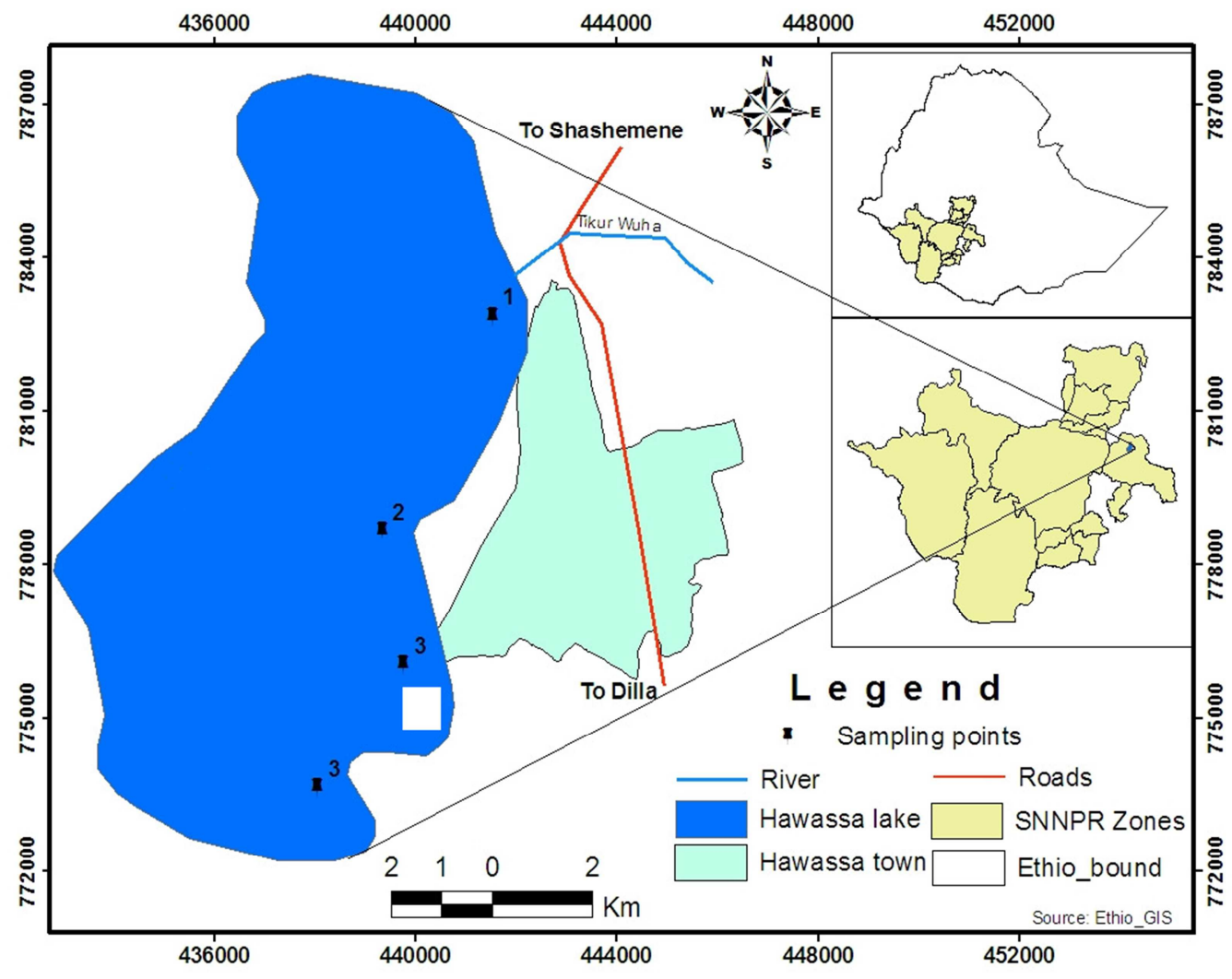

Fig. 1. Map of Lake Hawassa and the study areas. 


\subsubsection{Major Fish Production in Lake Hawassa}

Lake Hawassa is productive and one of the most fished lakes in the country. It has rich phytoplankton and zooplankton community that support large populations of six fish species. The most important commercial species is tilapia (Oreochromis niloticus), but there are also good populations of catfish (Clarias gariepinus) and barbus (Barbusintermedius) that account to the fishery of the lake. Of these, tilapia constitutes about $90 \%$ of the total production, while Catfish and Barbus contribute only about $7 \%$ and $2-3 \%$, respectively of the total annual production [20]. Tilapia and Barbus are caught exclusively by gill nets while Catfish is caught both by gill nets and also long lines. The other three species are not fished because of their small size and these include Barbus paludinosis, Aplocheilchthys antinori and Gara spp [5].

There are two groups of fishermen, i.e., cooperative member fishermen who operate at the southern side of the lake and another group of fishermen that operate at the northern side of the lake bounding the Oromia region. The first group of fishermen has a long time of fishing on the lake since fishery has started to establish in the lake some four decades ago. Whereas the latter group of fishermen consists a small number of fishermen and established some five years ago. There is a sort of conflicting interest unresolved between the two groups of fishermen and therefore fishing is conducted by the two groups sectorally. i.e., the cooperative fishermen operate at the southern one third of the lake while the fishermen at the north, about one third of the lake area. Thus the middle part of the lake is a kind of buffer zone, which is unfished at the moment.

\subsection{Method of Data Collection}

The data were collected from the cooperative fishermen landing site called fish market or informally known as Amora Gedel. The data mainly constitutes information on the tilapia fishery of the lake that are useful to assess the stock of tilapia and estimate the bio-economic optimum level of tilapia yield and biologically optimum level of fishing effort. Specifically the basic information collected included i) The length composition of tilapia caught by the fishery, ii) Total tilapia yield, iii) Fishing effort expanded and iv) the price of fish as well as cost of fishing operation.

\subsection{Sampling Regime and Data Collection}

The daily catch and yield data were collected from the fishermen for one year. Accordingly, the lake was visited on a daily basis from the beginning of February 2014 up to the end of February, 2015. These months hold fasting and non fasting season of the Ethiopian Orthodox church that was used to get better catch record data in the time in which the lake is lightly as well as intensively fished.

During each day of sampling, the total lengths of random samples of tilapia caught by fishermen were measured to the nearest $\mathrm{mm}$. Also the length measured fish were weighed as well as the total catch of each fisherman was weighed. The latter data was then used to estimate the total number of tilapia caught by the respective fishermen. Other data collected on a daily basis included number of nets set number of boats operated, the price of fish by size as well as cost of fishing operation.

\subsection{Data Summarization and Analysis}

The catch statistics data were summarized in a manner useful for stock assessment work using Jones length based cohort analysis Model and Length-based Thompson and Bell yield Prediction Model. The summarization and analysis were done by using Microsoft Office Excel (2007) software.

\subsubsection{Summarizing Length Composition Data}

The length composition catch data were summarized for tilapia to prepare a table of the average total annual catch of tilapia distributed by length groups. This was done as follows [9]; [10].

i. Length measurements recorded daily were grouped in to $2 \mathrm{~cm}$ length intervals to prepare a table of the length frequency of tilapia sampled each day during the sampling occasions.

ii. Estimating the total number of fish landed per day by each fisherman

This was estimated by multiplying the number of length measured fish by a conversion factor $(\mathrm{W} / \mathrm{w})$ where $\mathrm{W}=$ the total weight of the catch of the respective fisherman and $\mathrm{w}=$ sample weight of the length measured fish. Thus fish that were simultaneously counted and weighed were used to determine appropriate raising factor to convert records of the daily weight of the catch in to numbers.

iii. Estimating the length composition of the total daily catch

This was achieved by multiplying the total numbers caught per day by the relative frequency of each length group in the daily sample obtained under item ' $i$ ' above. The total length frequency of fish landed during the sampled day was then determined by summing the frequencies of respective length groups. Also the total numbers of fish landed during the sampling days were determined.

iv. Estimating the total number of tilapia caught during un sampled days of the year

Since the data were collected for 365 consecutive days (i.e. Twelve months, between the beginning of February 2014 and February 2015), the total number and weight of tilapia caught during the physical year was estimated using a raising factor. This was done by multiplying the average catch per day of the sampled 365 days of catch by the number of un sampled days during the year.

Since the catch and effort expanded differed during the fasting and non fasting days of the Ethiopian Orthodox Christians, the days of the year were divided into three categories as non fasting days of the week (i.e., days other than Wednesday and Friday), common fasting days of the week (Wednesday and Friday), and Major fasting seasons ('Hudade'i.e., 55 days between February and April as well as 
'Felseta' i.e., 15 days between $7^{\text {st }}$ and $22^{\text {th }}$ day of August). Accordingly, during the year, there were 229,70 and 66 days of non fasting, Major fasting and common fasting days, respectively. Therefore the average catch of the sampled non fasting days was used to estimate the total catch of the 229 non fasting days. Similarly, the average catch during the 365 sampled days of Wednesdays and Fridays was used to estimate the catch of the unsampled Wednesdays and Fridays Likewise, the average daily catch of the sampled major fasting days was used to estimate the total catch of the un ampled major fasting days. In a similar manner the total weight of the catch and effort expanded were estimated for the un sampled days of the year categorizing the dates into three categories as explained above.

v. Estimating the annual total length composition of fish landed.

This was done by raising the length frequency of the sampled 365 days of catch by an appropriate raising factor which was equal to $\mathrm{C} / \mathrm{c}$, in which ' $\mathrm{C}$ ' =the estimated total catch of fish during the whole year and ' $c$ ' = the total catch of fish during the 365 days of sampling. Over all 46,745 fish were length and weight measured during the 365 days of sampling. Therefore the length frequency produced using such a large sample size was considered adequate to give a good picture of the length frequency of the catch of tilapia in the lake.

\subsubsection{Estimating Average Weight and Price of Fish per Length Group}

The average weights of fish of each length group were approximated from the length-weight relationship established. Then the total weight of fish landed per year in each length group was estimated by multiplying the average weights with the corresponding frequencies of respective length group. Likewise, using average fish price data collected per length group, a similar procedure was followed to estimate the total annual value of fish landed in the respective length groups.

\subsubsection{Estimating Population Sizes and Fishing Mortalities Using the Jones Length Based Cohort Analysis}

The Jones length based cohort analysis model was used to estimate the population of tilapia and fishing mortality coefficient by length group. For this the total annual catch distributed by length group was used as the basic input data to get started with the analysis. This was done in three steps as follows

i). Estimating the population number of the largest length group in the catch. This was done as follows

$$
\mathrm{N}_{\text {terminal }}=\mathrm{C}_{\text {terminal }} *(\mathrm{Z} / \mathrm{F})_{\text {Terminal }}
$$

Where

$\mathrm{N}_{\text {terminal }}=$ the population of the largest length group in the catch

$\mathrm{C}_{\text {terminal }}=$ the catch of the largest length group and

$(\mathrm{Z} / \mathrm{F})_{\text {Terminal }}=$ the proportion of the total mortality to the fishing mortality of the largest length group in the catch

ii). Estimating the population numbers of consecutively younger length groups in the catch

This was done using equation 17 (page 20) as follows

$$
\mathrm{N}(\mathrm{L} 1)=[\mathrm{N}(\mathrm{L} 2) * \mathrm{H}(\mathrm{L} 1, \mathrm{~L} 2)+\mathrm{C}(\mathrm{L} 1, \mathrm{~L} 2)] * \mathrm{H}(\mathrm{L} 1, \mathrm{~L} 2)
$$

Here the terms are as defined earlier.

i). Estimating the fishing mortality rate of the respective length groups

Fishing mortality values for each length group was estimated using equation 18 as follows.

$$
\mathrm{F}(\mathrm{L} 1, \mathrm{~L} 2)=(1 / \Delta \mathrm{t}) * \ln [\mathrm{N}(\mathrm{L} 1) / \mathrm{N}(\mathrm{L} 2)]-\mathrm{M}
$$

Here the terms are also as defined before.

To use Equations 17 and 18, the following input data and parameters were prepared in advance.

- First a table of the total annual catch distributed by length group was prepared as described earlier

- Secondly estimates of the Von Bertalanffy growth parameters namely, $\mathrm{L}_{\infty}$ and $\mathrm{k}$ values for the tilapia stock of Lake Hawassa were obtained from previous age determination work as $\mathrm{L}_{\infty}=35 \mathrm{~cm}$ and $\mathrm{k}=0.28 \mathrm{yr}^{-1}[11$, $12,13]$.

- Thirdly, an estimate of the natural mortality coefficient (M) for tilapia which is equal to $0.35 \mathrm{yr}^{-1}$ was estimated using Pauly's empirical formula as follows.

$\ln \mathrm{M}=-0.00152-0.279 * \ln \mathrm{L}_{\infty}+0.6543 * \ln \mathrm{k}+0.463 * \ln \mathrm{T}$

Where values of $\mathrm{L}_{\infty}$ and kare as described above for the tilapia stock and $\mathrm{T}$ is the mean annual surface water temperature of Lake Hawassa which was equal to $21^{\circ} \mathrm{C}$ [12].

\subsubsection{Predicting Sustainable Bio-economic Fish Yield and Optimum Fishing Efforts}

The outputs of the above cohort analysis procedures were used as input data for the Thompson and Bell yield prediction model to predict sustainable fish yield and revenue at different levels of fishing mortalities $[14,15,16,10]$.

For the length based Thompson and Bell model, input data and sources comprised the following

i. The length composition of the annual total number of fish landed by the fishery. Obtained from field data collection (catch statistics data record).

ii. Mean weight and value of the landings per length group. Source: as in the above.

iii. Estimates of population numbers of fish and fishing mortality coefficient (F) by length group. Source: results of the Cohort analysis.

iv. An average estimate of natural mortality coefficient (M), and the Von Bertalanffy growth parameters ( $\infty \infty$ and $\mathrm{k}$ ). Same values as discussed earlier have been used.

The computation procedures of the Thompson and Bell model consisted of two main stages. First the above input data were used to estimate, fish yield and economic value of the yield obtained per year from the respective length group of fish. Summing the individual contribution of each length group gave estimates of the annual total sustainable yield and the corresponding total revenue obtained per year from the 
sale of the yield (economic value) $[17,10]$ estimates pertained to the fishing mortalities that correspond to the current level of fishing effort exerted on the tilapia stock.

The second step in the calculation procedure involved assessment of the effects of changes in the current level of fishing effort (and hence that of fishing mortalities) on the sustainable yield and economic value of the yield. This was done by predicting these outputs at higher and/or lower levels of fishing mortality coefficients pertaining to the respective length groups (F-at-length-array). i.e., the current fishing mortality values of the respective length groups were used as reference and these were increased and/or decreased by a certain raising factor (F-factor) to predict new values of sustainable yield, and value of the yield corresponding to the changed fishing mortalities [18, 10].

From this analysis, the value of F-factor that gave the maximum sustainable yield was considered as biologically optimum level of fishing mortality to be exerted on the stock. Correspondingly, the level of F-factor at which the economic value of the yield would be maximum, was considered as economically optimum level of fishing mortality that should be expanded to get the maximum return from the fishery [19]. Since there is a one to one correspondence between fishing mortality (F) and fishing effort (f), the value of F-factor chosen as optimum was used to recommend how much the current level of fishing effort need to be increased or decreased to get the maximum sustainable yield as well as the maximum economic yield from the stocks.

\section{Results and Discussion}

\subsection{Status of Lake Hawassa Fishery}

\subsubsection{Fishing Status of the Lake}

There were overall 172 registered cooperative member fishermen operating on the lake during the time of sampling (Table 1). These fishermen owned 42 boats and on average 375 nets were set daily on the lake. The nets are basically set to catch tilapia but these nets also catch some catfish (Clariasgariepinus) and rarely barbus (Barbusintermedius). Each net was on average $80 \mathrm{~m}$ long and $2.5 \mathrm{~m}$ wide and it had an average mesh width of $8 \mathrm{~cm}$ stretched mesh. Each fisherman on average owned 2.2 nets and about 8 to 9 nets were set per boat daily. Overall an estimated number of 136,925 nets were operated during the year of sampling (i.e., September 2013 to August, 2014 physical year). With this level of fishing effort, an estimated total number of 909,013 tilapia were caught during the year that weighed about $182,940 \mathrm{~kg}$. The estimated catch per net per day was 6.64 tilapia and it weighed about $1.34 \mathrm{~kg} /$ net/day (Table 1).

There are also some fishermen that operate at the northern side of the lake (near TikurWuha river) bounding the Oromia region and land their catch near the mouth of TikurWuha river. According to the information gathered from the cooperative members as well as preliminary survey conducted at the TikurWuha side of the lake, the fishermen that operate at the northern side use 14 boats exclusively fishing on tilapia and some 15 boats that exclusively fish on catfish using long lines. These fishermen approximately operate on the northern one third area of the lake. However due to logistics constraint, these fishermen could not be sampled and included in the above statistics.

Table 1. Statistics of tilapia fishery of Lake Hawassa during the time of sampling.

\begin{tabular}{ll}
\hline Operation Measurements & Value \\
\hline Total number of fishermen in operation & 172 \\
Average number of boat operated per day & 42 \\
Average nets set per day & 375 \\
Total number of nets set per year & 136925 \\
Total number of fish caught & 909013 \\
Total wt of catch $(\mathrm{kg})$ & 182940 \\
Catch per net (no./net/day) & 6.64 \\
Weight of catch per net (kg/net/day) & 1.34 \\
\hline
\end{tabular}

Source: Stock assessment work

\subsubsection{Length Composition of the Sampled Catch and Estimated Annual Catch}

Tilapia measuring in length from $14 \mathrm{~cm}$ up to $36 \mathrm{~cm}$ total length (TL) composed the catch of the fishermen during the time of sampling (Table 2). Amongst these, over $98 \%$ of the catch ranged in length between 18 to $28 \mathrm{~cm}$ in TL. More importantly the length groups 20 to $26 \mathrm{~cm}$ TL composed about $86 \%$ of the total catch (Table 2 ).

The length composition of tilapia catch did not appreciably change since the last 15 years. For instance according to [5] report, tilapia measuring in TL between 18 to $28 \mathrm{~cm}$ composed about $97 \%$ of the catch and those between 20 to $26 \mathrm{~cm}$ TL accounted for $88 \%$ of the catch. Similarly in 2004, the length group 18 to $28 \mathrm{~cm}$ TL accounted for $95 \%$ of the annual catch and those 20 to $26 \mathrm{~cm}$ made up $83 \%$ of the catch (Yosef, unpublished data). The reason for the similarity of the length composition of the catch may be because of usage of similar mesh size nets since the last 15 or so years. Unlike this focused group discussion with fishermen of the lake indicated that some two to three decades ago, tilapia measuring up to 35 to $40 \mathrm{~cm}$ TL were very common in the fishermen catch and the average catch size of tilapia was 25 to $30 \mathrm{~cm}$ TL. This may be the time during when the fishing pressure was quite low.

According to [12], the length at first maturity of tilapia in Lake Hawassa was about $20 \mathrm{~cm}$ TL. In the present result fish below $20 \mathrm{~cm}$ composed about $10 \%$ of the total catch (Table 2 ). Although not still alarmingly high, considerable portion of the fishermen catch composed immature tilapia that have not yet reproduced at least once in their lifespan. Thus, it seems reasonable to slightly increase the width of the mesh of nets used by fishermen. To be fair nets below $8 \mathrm{~cm}$ mesh width should be totally prohibited from being used by fishermen.

The total annual catch of tilapia during the sampled year (At the beginning of February 2014 to the end of February 2015) was estimated to be slightly over 900,000 fish (Table 2). Compared to the catch in 2004, which was about 3 million fish (Yosef, unpublished data), the current catch was only one third of the previous. During that time, fishermen used nearly 1500 
nets per day, which is about 4 folds greater than the current effort (see Table 1)

Table 2. Fish caught during the 365 days of sampling (at the beginning of February 2014 and end of February 2015) and estimated total annual catch by length group.

\begin{tabular}{llll}
\hline $\begin{array}{l}\text { Length } \\
\text { group (cm) }\end{array}$ & $\begin{array}{l}\text { Total caught/90 } \\
\text { days (number) }\end{array}$ & $\begin{array}{l}\text { Estimated } \\
\text { annual catch } \\
\text { (number) }\end{array}$ & $\begin{array}{l}\text { Proportion of length } \\
\text { group composition } \\
\text { from the total catch (\%) }\end{array}$ \\
\hline $14-16$ & 138 & 580 & 0.06 \\
$16-18$ & 1847 & 7758 & 0.85 \\
$18-20$ & 18832 & 79101 & 8.70 \\
$20-22$ & 68850 & 289193 & 31.81 \\
$22-24$ & 82049 & 344633 & 37.91 \\
$24-26$ & 34857 & 146409 & 16.11 \\
$26-28$ & 7992 & 33568 & 3.69 \\
$28-30$ & 1429 & 6003 & 0.66 \\
$30-32$ & 286 & 1200 & 0.13 \\
$32-34$ & 85 & 357 & 0.04 \\
34 \&above & 50 & 210 & 0.02 \\
Total & 216415 & 909013 & 100 \\
\hline
\end{tabular}

Source: Stock assessment work

\subsection{Estimates of Population Number and Fishing Mortality Coefficient by Length Group of Tilapia in Lake Hawassa}

Table 3 below gives estimates of population number and fishing mortality coefficient by length group of tilapia that composed the fishery. The estimates are made using John's length based cohort analysis model [21]. The second column is the total number of fish caught per year in each length group estimated based on catch statistics record. Estimates of population numbers $(\mathrm{N}(\mathrm{L} 1))$ and Fishing mortality coeffecients $(\mathrm{F}(\mathrm{L} 1, \mathrm{~L} 2))$ shown by columns 3 and 4 , respectively are direct out puts of the Jones length basedcohort analysis.

Table 3. Estimates of population numbers, fishing mortalities and other parameters by Length group. Values are calculated using Jones length based cohort analysis.

\begin{tabular}{|c|c|c|c|}
\hline $\begin{array}{l}\text { Length } \\
\text { group (cm) } \\
\text { L1, L2 }\end{array}$ & $\begin{array}{l}\text { Total annual catch } \\
\text { (number) } C(L 1, L 2)\end{array}$ & $\begin{array}{l}\text { Population } \\
\text { number } \mathbf{N} \\
\text { (L1) } \\
\end{array}$ & $\begin{array}{l}\text { Fishing } \\
\text { mortality }\left(\mathrm{yr}^{-1}\right) \\
\text { F(L1,L2) }\end{array}$ \\
\hline $14-16$ & 580 & 1847265 & 0.0009 \\
\hline $16-18$ & 7758 & 1629490 & 0.01 \\
\hline $18-20$ & 79101 & 1410746 & 0.14 \\
\hline $20-22$ & 289193 & 1133280 & 0.64 \\
\hline $22-24$ & 344633 & 683208 & 1.38 \\
\hline $24-26$ & 146409 & 243987 & 1.59 \\
\hline $26-28$ & 33568 & 60707 & 1.16 \\
\hline $28-30$ & 6003 & 15653 & 0.53 \\
\hline $30-32$ & 1200 & 5414 & 0.20 \\
\hline $32-34$ & 357 & 1987 & 0.11 \\
\hline $34 \&$ above & 210 & 323 & 0.65 \\
\hline
\end{tabular}

Source: Stock assessment work

Over all over 7 million tilapia population has been estimated to exist in the fished part of the lake as obtained by summing the population numbers of the respective length groups that composed the fishery given by column 3 (Table 3 ). This estimate pertains to the population of only the southern one-third of the area of the lake where the fishery is active. As explained above, the sampled fishery, which was run by the fishermen cooperatives operates only at the southern one-third of tha lake area. According to Yosef (unpublished data), the total population number of tilapia that composed the fishery estimated in 2004 was some 30 million fish. The latter estimate was for the whole lake and rasining the present estimate by a factor of 3 to 4 times gives a comparable estimate as that of the 2004 estimate.

As shown by column 4 of table 3, the length groups 20 to 30 $\mathrm{cm}$ fish shouldered heavy fishing mortality rate bearing above 0.5 fishing mortality per year. Although tilapia starting from 14 to $16 \mathrm{~cm}$ were recruited to the fishery, most of the fishing pressure relied up on length groups starting $22 \mathrm{~cm}$ to $28 \mathrm{~cm}$. As estimated by the model, over 1.8million tilapia of 14 to 16 $\mathrm{cm}$ fish are recruited to the fishery every year at the fished part of the lake (Table 3). According to the estimate made in 2004 (Yosef, unpublished data), an average number of about 6 million tilapia recruits annually to the fishery in the whole lake attaining the length of 15 to $16 \mathrm{~cm}$. Also, according to [20], an average number of about 5.6 million tilapia recruits to the fishery of Lake Hawassa attaining a total length of $16 \mathrm{~cm}$. Since the latter two are estimates based on whole lake data, the present recruitment estimate, which only accounts to one-third of the lake area, when raised by a factor of 3 gives nearly comparable recruitment rates estimated for the whole lake as obtained by previous authors.

\subsection{Fish Yield and Revenue}

Table 4 below gives estimates of total annual yield of tilapia (tons) and the corresponding revenue obtained (ETB) from the sale of the fish. Values in columns 2 are the annual catch of the respective length group fish displayed in previous tables and they are shown here to illustrate the intermediary calculation steps. The mean weight of fish $(\mathrm{kg})$ shown by column 4 are the average weights of each length group of tilapia estimated using the length weight relationship expressed by the following equation (Elias Dadebo, Unpublished data).

$$
\mathrm{Wt}(\mathrm{gm})=0.013 * \mathrm{~L}^{3.085}
$$

The coefficient of determination $\left(\mathrm{R}^{2}\right)$ value for the relationship was 0.99 indicating that the estimated total weight for the respective length groups is $99 \%$ valid as the measured length of each length group.

The current total yield pertaining to the respective length group (column 4) was obtained by multiplying the total catch of the respective length group by the corresponding mean weight values. Values in column 5 (Table 4) are mean fish price paid for the respective length groups of tilapia at the time of sampling. These were determined by collecting the price data of fish sold during the 365 days of sampling. Fishermen categorize their catch into four size groups as 
below $23 \mathrm{~cm}, 24$ to $26 \mathrm{~cm} 27$ to $31 \mathrm{~cm}$ and above $32 \mathrm{~cm}$ and fish of the respective length group were sold with an average price of 4, 6, 8 and $10 \mathrm{ETB} /$ fish, respectively (Column 5, Table 4). Accordingly, the total revenue obtained from the sale of each length group (Column 6 of Table 4) were calculated by multiplying values of the total catch of the respective length group by the corresponding average price of each length group. In due regard, the total annual yield of tilapia and total revenue shown at the bottom of columns 4 and 6, respectively (Table 4) are obtained by summing up the yield and revenue, respectively of each length group that composed the fishery.

The annual total yield of tilapia during the sampled year was 182.94 tons and it generates total revenue of $4,158,759.60$
ETB for the fishermen who work as members of the cooperative. According to [5], the estimated fish yield in the year 1995 and 1996 was 466 and 533 tons.

[20] also estimated a total annual yield of 520 tons of tilapia/year as harvested by the fishermen cooperatives.

The estimate in 2003-2004 was about 640 tonns/year (Yosef, unpublished data). As mentioned earlier, during the time of sampling, the fishermen were only fishing at about one-third of the lakes area. Therefore raising the current estimate by a factor of 3 gives a yield estimate close to 550 tons/year, which can be an estimate for the whole lake area. Thus the current yield estimate can be considered to be comparable to the previous estimates when raised by a factor of 3 .

Table 4. Estimates of total yield and revenue obtained from the sale of fish by length group under the current level of fishing effort for the tilapia stock of Lake Hawassa.

\begin{tabular}{|c|c|c|c|c|c|}
\hline $\begin{array}{l}\text { Length } \\
\text { group(L1,L2) }\end{array}$ & $\begin{array}{l}\text { Current annual catch } \\
\text { C(L1,L2) }\end{array}$ & $\begin{array}{l}\text { Mean weight (kg) } \\
\text { W(L1,L2) }\end{array}$ & $\begin{array}{l}\text { Current yield (tons/year) } \\
\text { Y(L1,L2) }\end{array}$ & $\begin{array}{l}\text { Average fish price } \\
\text { (ETB)/Fish P(L1,L2) }\end{array}$ & $\begin{array}{l}\text { Current Revenue } \\
\text { (ETB/year) R(L1,L2) }\end{array}$ \\
\hline $14-16$ & 580 & 0.06 & 0.03 & 4.00 & 2323.13 \\
\hline $16-18$ & 7758 & 0.08 & 0.63 & 4.00 & 31057.77 \\
\hline $18-20$ & 79101 & 0.11 & 9.08 & 4.00 & 316983.93 \\
\hline $20-22$ & 289193 & 0.16 & 45.38 & 4.00 & 1163958.66 \\
\hline $22-24$ & 344633 & 0.21 & 72.30 & 4.00 & 1400590.15 \\
\hline $24-26$ & 146409 & 0.27 & 40.12 & 6.00 & 901383.03 \\
\hline $28-30$ & 6003 & 0.42 & 2.61 & 8.00 & 49463.73 \\
\hline $30-32$ & 1200 & 0.52 & 0.65 & 8.00 & 9951.58 \\
\hline $32-34$ & 357 & 0.63 & 0.25 & 10.00 & 4051.76 \\
\hline \multirow[t]{2}{*}{$34 \&$ above } & 210 & 0.82 & 0.17 & 10.00 & 2102.19 \\
\hline & & \multicolumn{2}{|c|}{ Total Yield/year 182.94} & \multicolumn{2}{|c|}{ Total Revenue/year 4,158,760 } \\
\hline
\end{tabular}

Source: Stock assessment and yield prediction

\subsection{Estimated Cost of Fishing Operation and Net Profit}

The cost of fishing operation included the cost of boats, gillnets and labor cost paid for operating the fishing gear (Table 5). There were 42 boats in operation daily by the cooperative member fishermen. According to the price information gathered from fishermen, the cost of making one boat was 2000 ETB and it served for about 5 years. Accordingly the annual depreciation cost of a boat was estimated to be 400 ETB. Multiplying this by the total number of boats operated per day gave the total cost of boats as 16,800 ETB. Similarly according to the information gathered from fishermen, the cost of making a gillnet was estimated to be 939 ETB and it lasts for two years. Thus the annual depreciation cost of a net was estimated at 470 ETB. Since on average 375 nets were set daily, this gives an estimated total cost of nets as 176,250.0 ETB.

Table 5. Estimated cost of fishing operation of Lake Hawassa fishermen.

\begin{tabular}{ll}
\hline Item & Value \\
\hline 1. Boat & \\
Cost of fishing boat (ETB/boat) & 2000.00 \\
Service year & 5 years \\
Annual Depreciation cost (ETB/boat) & 400.00 \\
Average number of boat operated per day & 42 \\
Total cost of boat per year (ETB) & $16,800.00$ \\
2. Net & \\
\hline
\end{tabular}

\begin{tabular}{ll}
\hline Item & Value \\
\hline Cost of net making (ETB/net) & 939.00 \\
Service year & 2 years \\
Annual depreciation cost (ETB/net) & 470.00 \\
Average number of net set per day & 375 \\
Total cost of net per year (ETB) & $176,250.00$ \\
3. Labor & \\
Labor cost (ETB/ man power/day) & 25 \\
Operating person per boat & 2 \\
Average number of boats operated per day & 42 \\
Total labor cost/day (ETB) & 2100.00 \\
Total labor cost per year (ETB) & $766,500.00$ \\
Total cost of fishing operation per year (ETB) & $959,550.00$ \\
\hline
\end{tabular}

Source: stock assessment and yield prediction

Fishermen that owned boats and nets do not set their gill nets themselves. Instead, they hire daily laborers (commonly two fishing boys per boat) to do the job for themselves and they pay 25 ETB per person per day. Accordingly the labor cost per boat daily was 50 ETB. Since on average 42 boats were operated daily, the total labor cost per day was estimated to be 2100 ETB. i.e., this gives a total labor cost of fishing per year as 766,500.0 ETB.

The overall total cost of fishing operation per year was therefore estimated as the sum total of the three itemized costs as 959,550.0 ETB (Table 5). In due concern, the cooperative fishermen earned an estimated net profit of 3,199,210 ETB during the sampled year. This amount divided by the total 
number of 172 fishermen that were in operation during the year gave an estimated average net profit per person per year of 18,600 ETB. i.e. a monthly average income of 1550 ETB per fisherman. This in fact does not include the meager income they generate from the sale of catfish and occasionally from barbus catch.

\subsection{Predicting Yield and Revenue Obtained from the Fishery}

\subsubsection{Yield and Revenue Predictions Under the Assumption of Doubling Rate of Fishing Effort}

Total yield and total revenue shown in table 4 were obtained under the current fishing effort level which resulted in fishing mortality shown in column 4 of table 3 . Accordingly, these current fishing mortality rates of the respective length groups were considered as reference fishing mortalities and they were raised and lowered by certain factors (F-factors) to predict yield and revenue at the changed level of fishing mortalities. For example, Table 6 below shows results of predictions made under the assumption of doubling of the fishing effort expanded on the tilapia stock of Lake Hawass. Thus the new $F$ values shown by column 2 (Table 6) are twice the value of the current fishing mortalities shown in column 4 of table 3 . Column 6 shows the mean weight of each length group and the values are same as in column 3 of Table 4 . The rest of the columns contain predicted values under the changed fishing mortality levels.

Table 6. Output from the length based Thompson and Bell model for the tilapia stock (Oreochromis niloticus) from Lake Hawassa predicted based on the assumption of doubling of the current fishing effort.

\begin{tabular}{|c|c|c|c|c|c|c|c|}
\hline $\begin{array}{l}\text { Length } \\
\text { group(L1,L2) }\end{array}$ & $\begin{array}{l}\text { Changed } \\
\text { F(L1,L2) }\end{array}$ & $\begin{array}{l}\text { Predicted opulation } \\
\text { N(L1,L2) }\end{array}$ & $\begin{array}{l}\text { Total Mortality } \\
\text { D(L1,L2) }\end{array}$ & $\begin{array}{l}\text { Predicted } \\
\text { catch/year } \\
\text { C(L1,L2) }\end{array}$ & $\begin{array}{l}\text { Mean } \\
\text { weight (kg) } \\
\text { W(L1,L2) } \\
\end{array}$ & $\begin{array}{l}\text { Predicted Yield } \\
\text { (tons/year) } \\
\text { Y(L1,L2) } \\
\end{array}$ & $\begin{array}{l}\text { Predicted Total } \\
\text { Revenue (ETB/year) } \\
\text { R(L1,L2) }\end{array}$ \\
\hline $14-16$ & 0.002 & 1847265 & 218320 & 1161 & 0.055 & 0.06 & 4645.49 \\
\hline $16-18$ & 0.026 & 1628945 & 225399 & 15453 & 0.081 & 1.26 & 61811.25 \\
\hline $18-20$ & 0.280 & 1403546 & 338980 & 150613 & 0.115 & 17.25 & 602453.12 \\
\hline $20-22$ & 1.280 & 1064566 & 572013 & 449220 & 0.156 & 70.06 & 1796879.36 \\
\hline $22-24$ & 2.752 & 492554 & 385187 & 341722 & 0.206 & 70.56 & 1366887.86 \\
\hline $24-26$ & 3.182 & 107367 & 87956 & 79240 & 0.267 & 21.16 & 475437.50 \\
\hline $26-28$ & 2.320 & 19411 & 13885 & 12065 & 0.339 & 4.09 & 96522.45 \\
\hline $28-30$ & 1.067 & 5526 & 2674 & 2014 & 0.422 & 0.85 & 16109.56 \\
\hline $30-32$ & 0.399 & 2852 & 1471 & 783 & 0.519 & 0.41 & 6266.58 \\
\hline$\geq 34$ & 1.300 & 208 & 208 & 164 & 0.823 & 0.13 & 1637.52 \\
\hline Total & & & & & & 186.11 & 4433245.90 \\
\hline
\end{tabular}

Source: Stock assessment and yield prediction

Since a change in fishing mortality obviously results in a change in population number of fish in the water, new estimates of population numbers in each length group were predicted as shown in column 3 of Table 6 . Column 4 (Table 6) gives the total number of deaths expected while the fish grow from length $\mathrm{L} 1$ to length $\mathrm{L} 2$, i.e., $\mathrm{D}(\mathrm{L} 1, \mathrm{~L} 2)$ and this is equal to $\mathrm{N}(\mathrm{L} 1)-\mathrm{N}(\mathrm{L} 2)$. From this total death, the fraction those die due to fishing make up the total catch. Accordingly the catch per length interval (Column 5) corresponding to the changed fishing mortality were calculated by multiplying the values in column 4 by F/ Z, where $\mathrm{F}$ and $\mathrm{Z}$ are the new fishing and total mortality values corresponding to the changed fishing efforts.

Then the predicted catch in number (values of column 5) were multiplied by the mean weight of each length group (values of column 6) to estimate the expected yield under the changed fishing mortality (column 7). Similarly the predicted total revenue under the changed fishing mortality (column 8) was obtained by multiplying the predicted catch by the corresponding fish price.

In due regard, the total yield and total revenue levels to be expected under the new level of fishing effort are indicated at the lower end (last raw) of Table 6. These values are obtained by summing up the contributions of each length group. This analysis shows that the total yield to be expected from doubling of the fishing effort (i.e., 186.11 tons) is not too far from the yield obtained at the current level of fishing pressure (i.e., 182.94 tons). Hence the effect of doubling the effort would have a contribution of a slight increment in the total yield obtained from the stock. In the same manner the total revenue would increase from the current amount $(4,158,759.6$ ETB) to 4,433,245.9 ETB if the fishing effort expanded on the stock is doubled.

Doubling the fishing effort would also result in an increase in the cost of fishing operation. Accordingly the current total cost of fishing operation estimated above, i.e., 959,550.0 ETB /year (Table 5) would also increase to 1,919,100 ETB if the current fishing effort is doubled. Accordingly, deducting this amount from the total predicted revenue would give a net profit per year of 2,514,146 ETB per year. Hence doubling the current fishing effort would reduce the net profit obtained under the current level of fishing effort (i.e., 3,199,210) by 685,064 ETB. Therefore doubling the current fishing effort is rather uneconomical although the total yield obtained slightly increases. 


\subsubsection{Yield and Revenue Predictions Under Different Levels of Fishing Efforts}

Table 7. Values of total annual yield (tons), and net annual profit obtained from tilapia (Oreochromis niloticus) stock of Lake Hawassa predicted using values of $F$-factor ranging from 0 to 2 .

\begin{tabular}{lll}
\hline F-factor & $\begin{array}{l}\text { Predicted total annual } \\
\text { yield (tons) }\end{array}$ & $\begin{array}{l}\text { Predicted total annual net } \\
\text { profit (ETB) }\end{array}$ \\
\hline 0.1 & 72.89 & 1508311 \\
0.2 & 111.98 & 2279211 \\
0.3 & 135.71 & 2715850 \\
0.4 & 151.19 & 2973067 \\
0.5 & 161.73 & 3123586 \\
0.6 & 169.12 & 3206159 \\
0.7 & 174.39 & 3243313 \\
0.8 & 178.20 & 3248993 \\
0.9 & 180.95 & 3232257 \\
1 & 182.94 & 3199210 \\
1.1 & 184.35 & 3154089 \\
1.2 & 185.34 & 3099907 \\
1.3 & 186.00 & 3038846 \\
1.4 & 186.42 & 2972513 \\
1.5 & 186.64 & 2902108 \\
1.6 & 186.72 & 2828534 \\
1.7 & 186.68 & 2752481 \\
1.8 & 186.55 & 2674475 \\
1.9 & 186.36 & 2594925 \\
2 & 186.11 & 2514146 \\
\hline
\end{tabular}

Source: stock assessment and yield prediction

The results summarized in Table 6 are predictions corresponding to a one-time change in the fishing pressure. Such predictions have been evaluated for different values of fishing mortalities so as to see the full spectrum of the effect of changing the fishing effort on the stock. For instance, Table 7 shows summary of yield and net profit predicted using values of F-factors ranging from 0 to 2. Predictions were made based on the length based Thompson and Bell model. The reference $\mathrm{F}$ array is shown in column 6 of Table 3 It has been multiplied by each value of F-factor shown in column 1 of Table 7 to produce the new fishing mortality coefficient for each length group. Then values of yield and net profit were predicted using the new F-array. In due regard, Column 2 and 3 show expected values of total yield and total revenue for each of the F-factors. These values have been obtained after going through the whole procedure of computations illustrated for Table 6. Note that the total yield and net profit values corresponding to the F-factor 1 are same as in Table 4 because no change has been done to the reference F-array. Similarly the total yield and net profit levels corresponding to the F-factor of 2 in Table 7 are same as in Table 6 and again this is because an F-factor of 2 means doubling of the reference F-array.

NB. Shaded values refer to the maximum sustainable yield (MSY) and net profit at MEY as well as to the corresponding optimum level of F-factor. Shaded.

According to the above analysis, the value of maximum sustainable yield of the tilapia stock is 186.72 tons and this is obtained at an F-factor of 1.6 (Table 7). This implies that the Lake has a potential for the increment of current level of fishing effort by a factor of 1.6 to achieve the maximum sustainable yield. By contrast, the maximum economic yield (i.e., the yield level at which the net profit is maximum) of tilapia stock is 178.2 tons and this is obtained at an F-factor of 0.8 (Table 7) This implies that the current level of fishing effort has to be reduced by a factor of 0.8 to achieve the maximum economic yield which is the level of yield that maximize the net benefit earned by the fishermen predicted as 3,248,993 ETB.

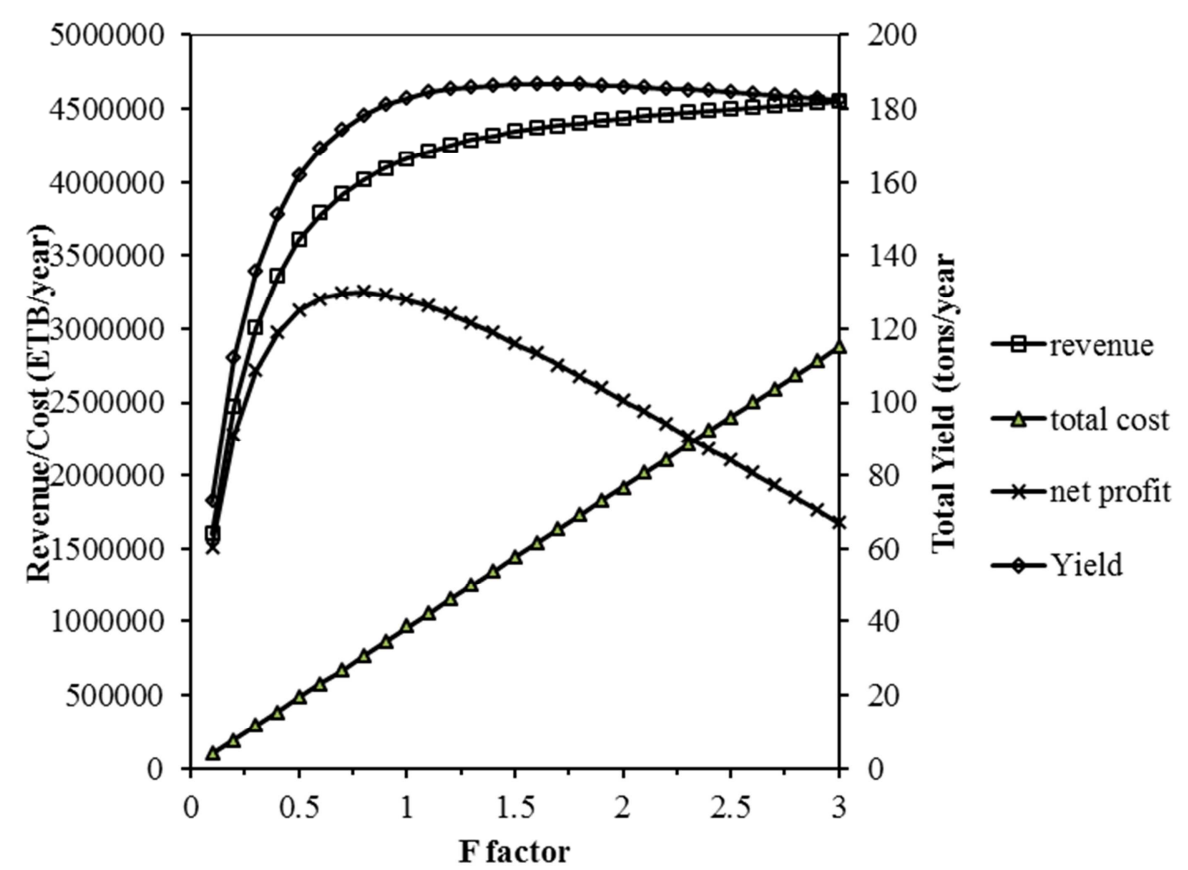

Fig. 2. Predicted total annual yield (tons), revenue, total cost, and net profit at different values of F-factors for the tilapia stock of Lake Hawassa. 


\section{Conclusion and Recommendation}

\subsection{Conclusion}

According to the results of the study, the lake's fishery has different status from biological and economic perspectives. Its biological status could have a potential to produce more but economically it might not be profitable, there is no incentive to increase burden on production. Maximum sustainable yield might be the most desirable equilibrium for a fishery if costs to harvest, revenues or net profit in general are neglected. The maximum sustainable yield of the Lake is 186.72 tones/yr. Even if, the Maximum Economic yield was estimated at 178.20 tones/yr, the current harvest is estimated at about $182.94 \mathrm{t} / \mathrm{yr}$. harvesting on Lake Hawassa fishery to its maximum sustainable yield may help in the reduction of the scarcity of fish in relation to its demand. However, the cost of harvesting to the MSY would be high.

This study has tried to address objectives of the study as: the existing harvest activities of the Lake are reviewed and found out that, it kept the status of Lake Hawassa biologically as well as economically inefficient.

\subsection{Recommendation}

Based on the findings of the stock assessment, the following measures are recommended;

- In order to manage the fish resource, harvesting at the level of its MSY could be considered as wise decision. This could be possibly happened by enhancing revenue or reducing the cost of production otherwise it might need subsidy. However, according to the situation of the country and from the long run impact on dependency, subsidizing the fishery might not be appropriate measure. Therefore, fishermen cooperatives with the cooperation of government cooperatives offices should reduce their cost by directly import net making twine in order to decrease the margin by retailer, as it is the major cost on the fishery sector. Reduction of cost will increase the Yield level to its maximum sustainable yield by increasing fishing effort level.

\section{Acknowledgements}

We thank Hawassa University, Wondo Genet College of Forestry and Natural Resources Research and Development Office for financial support and also we thank fishermen's Ketema Mengistu and Asefsa Dibo for their assistance during sampling Collection.

\section{References}

[1] MacLean, J. A. and Evans, D. O. 1981. The stock concept, discreteness of fish stocks and fisheries management. Canadian Journal of Fisheries and Aquatic Sciences, 38: 1889-1898.

[2] FAO. 2010. The State of World Fisheries and Aquaculture 2010:
FAO, Fisheries and Aquaculture Department. Vialedelle Terme di Caracalla, 00153 Rome, Italy.

[3] Alverson, D. L. and Dunlop, K. 1998. Status of World Marine Fish Stocks: Fisheries Research Institute, School of Fisheries, University of Washington Seattle, November 1998. Washington 98195.

[4] Sarnowski, V. A. 2004. The Artisanal Fisheries of Lake Albert and the Problem of Overfishing. Conference on International Agricultural Research for Development. Geographisches Institut, Johannes Gutenberg Universität Mainz, 55099 Mainz, October 5-7, 2004. Berlin, Germany

[5] LFDP. 1997. Lake management plans. Lake Fisheries Development Project, Phase II, Working Paper 23. $2^{\text {nd }}$ ed. Ministry of Agriculture, Addis Ababa.

[6] FAO. 2000. The State of World Fisheries and Aquaculture 2000: FAO, Fisheries and Aquaculture Department. Vialedelle Terme di Caracalla, 00153 Rome, Italy.

[7] FAO. 2009a. The State of World Fisheries and Aquaculture 2008: FAO, Fisheries and Aquaculture Department. Vialedelle Terme di Caracalla, 00153 Rome, Italy.

[8] FAO. 2009b. Factors of unsustainability and over exploitation in marine fisheries views from the southern Mediterranean, West Africa, Southeast Asia and the Caribbean. FAO Fisheries and Aquaculture Circular No. 1037. Vialedelle Terme di Caracalla, 00153 Rome, Italy

[9] Pauly, D. 1984a. Length converted catch curves. A powerful tool for fisheries research in the tropics (Part II). ICLARM Fishbyte, 2 (1): 17-19

[10] Sparre, P. and Venema, S. C. 1992. Introduction to tropical fish stock assessment. Part 1. Manual. FAO Fisheries Technical Paper No. 306.1, 376 p.

[11] Yosef T-G. 1990. Age determination and growth estimation of immature Oreochromis niloticus Pisces: Cichlidae) in Lake Awassa, Ethiopia MSc thesis University of Waterloo, Waterloo, Canada.

[12] Yosef T-G. 2002. Comparative age and growth assessment of the African catfish, Clarias gariepinus Burchell (Clariidae) and, Nile perch, Lates niloticus, Linn (Centropomidae) in the three southern Rift Valley lakes of Ethiopia (Lakes Awassa, Abaya and Chamo). PhD thesis Addis Ababa University, $160 \mathrm{p}$.

[13] Demeke, A. 1998. Age and growth determination of Ttilapia, Oreochromisniloticus L. (Pisces: Cichlidae) in some lakes in Ethiopia. Ph. D. thesis, Addis Ababa University, Ethiopia. 115 p.

[14] Thompson, W. F. and Bell, F. H. 1934. Biological statistics of the pacific halibut fishery. 2. Effects of changes in intensity upon total yield and yield per unit of gear. Report of the international Fisheries (Pacific halibut) Commission, 8: 49 p.

[15] Pauly, D. and Morgan, G. R. 1987. Length based methods in fisheries research. ICLARM Conference proceedings, 13: $468 \mathrm{p}$.

[16] Schnute, J. 1987. A general fishery model for a size- structured fish population. Canadian Journal of Fisheries and Aquatic Science, 44 (5): 924-940.

[17] Meagrey, B. A. 1989. Review and comparison of age-structured stock assessment models from theoretical and applied points of view. American Fisheries Society Symposium, 6: 8-48. 
[18] Venema, S. C. Christensen, J. M. and Pauly, D. 1988. Training in tropical fish stock assessment: a narrative of experience. FAO Fisheries Technical Paper, (389): 1-15p.

[19] Sparre, P. and Willmann, R. 1992. Computer programs for bio-economic analysis of fisheries. BEAMR manual. Analytical bio-economic simulation of space structured multi species and multi-fleet fisheries. FAO Computerized Information Series (Fisheries) (3): 248 p.
[20] Reyntjens, D. and Tesfaye, W. 1998. Fisheries management - a review of the current status and research needs in Ethiopia. SINET: Ethiopian Journal of Science, 21 (2) 231-266.

[21] Jones, R. 1984. Assessing the effects of changes in exploitation patterns using length composition data (with notes on VPA and Cohort analysis). FAO Fisheries Technical Paper, 256: 118 p. 